
https://doi.org/10.30534/ijeter/2020/193892020

\title{
Calculation and improving the Overall Equipment Effectiveness for Textile Industry Machine
}

\author{
D.Phanindra Kshatra ${ }^{1}$, Ratna Prasad Paladagu ${ }^{2}$, Praneeth Inturi $^{3}$, G.Sree Vishnu ${ }^{4}$, V.S.V.S.Badrinath ${ }^{5}$ \\ ${ }^{1}$ Koneru Lakshmaiah Education Foundation, India, phanindra@ kluniversity.in \\ ${ }^{2}$ Koneru Lakshmaiah Education Foundation, India, prprasadc_me@kluniversity.in \\ ${ }^{3}$ Koneru Lakshmaiah Education Foundation, India, praneethinturi1999@gmail.com \\ ${ }^{4}$ Koneru Lakshmaiah Education Foundation, India, sreevishnusaichandang@gmail.com \\ ${ }^{5}$ Koneru Lakshmaiah Education Foundation, India, vajjabadrinath@gmail.com
}

\begin{abstract}
Textile industry is one of the largest and oldest industries. It is one of the important industries to meet the demand for cloth making and export to various countries for the improvement of economy. As described by India Brand Equity Foundation, textile industry accounts for $4 \%$ of nation GDP and nearly 45 million people are employed in this sector in India. The domestic as well as the export market is around 100 billion dollars. Although the manufacturing techniques that are present in $21^{\text {st }}$ century are highly automized with minimum human intervention, a great degree of maintenance is labor intensive work and mostly depends on human inputs. Since the machines are automated and are of high investment it is imperative to effectively utilize the equipment both in terms of quality and productivity. The drive of Overall Equipment Effectiveness (OEE) is to measure the performance of the equipment for which it is intended to function and to reach the production target that is scheduled for work. The main purpose of this paper is to calculate the OEE for a textile industry, with the help of theoretical framework it is determined to understand and implement OEE for a cost-effective solution in organization.
\end{abstract}

Key words: Productivity, Overall Equipment Effectiveness (OEE), Total Productive Maintenance (TPM), Lean Manufacturing, Eight pillars, Textile Machinery

\section{INTRODUCTION}

In India, contribution of textile industry accounts for $14 \%$ of production and 15\% of country's earnings [1]. India is the largest producer of Cotton and Jute in the world [1].

The manufacturing yarn spinning sector in India accounts for $42 \%$ and has 50 million spindles and 8 million rotors in the world [1]. With this increase in the manufacturing year after year, the textile industry should focus on strategies to improve productivity, quality, resources utilization and reduce cost of production and improve sustainable production planning [2][3].

Although most of the textile industry equipment is automated, in recent years maintenance plays an important role in such industries and since this being a continuous production system, breakdown of a single machine leads to all the other processes being affected by it [4][5]. In general, performance of the equipment which is in normal working condition is affected due to six major losses [4][5]. Total Productive maintenance (TPM) is one such methodology which will solve this problem. Developed by Nakajima (1988), TPM is a maintenance methodology which help to study equipment at different stages of its life cycle and helps in improving its efficiency [4][5]. Overall Equipment Effectiveness (OEE) is a Key Performance Indicator (KPI) to monitor and control performance efficiency of the equipment [6]. The case study is from a textile plant and this paper aims to explore all the possibilities to improve the OEE for a textile industry machine.

\section{THEORETICAL FRAMEWORK 2.1 Total Productive Maintenance (TPM)}

The manufacturing system to be successful in an organization should be effective and efficient in all the aspects of maintenance. One of the most used approaches in any industry is Total Productive Maintenance (TPM) which helps to maintain and continuously improve the performance of equipment time over the time. Seiichi Nakajima defined TPM as an "innovative approach to maintenance that optimizes equipment effectiveness, eliminates breakdowns, and promotes autonomous maintenance by operators through day-to-day activities involving the total workforce" [7]. TPM is a strategy which helps to maximize the equipment effectiveness. TPM is an 8-pillar approach . 


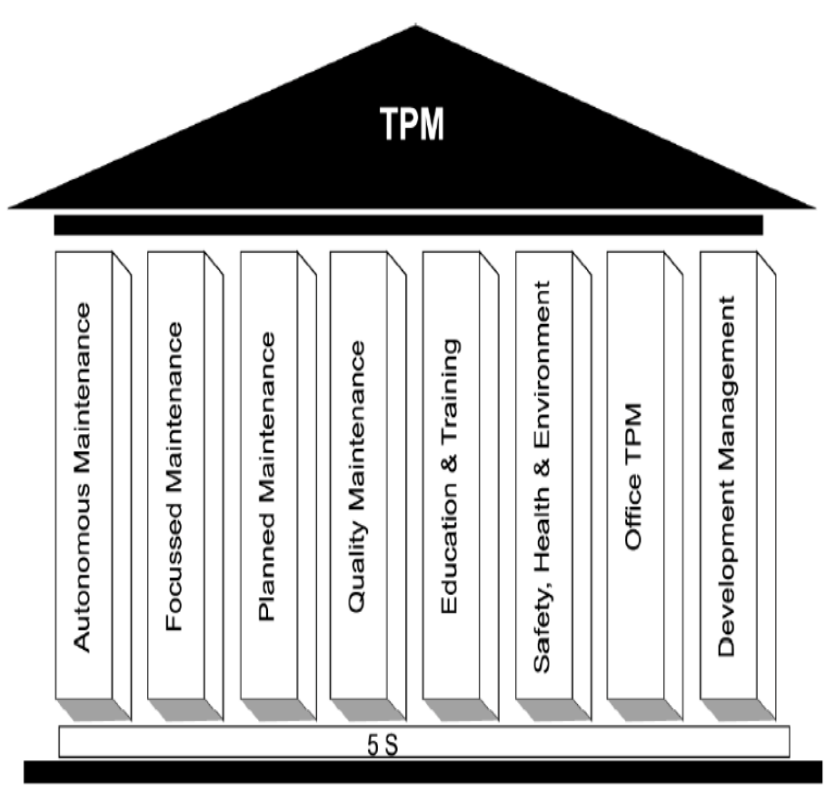

Figure 1:: Eight Pillars Approach for TPM [7]

Table 1: TPM Pillars and their Moto

\begin{tabular}{|l|l|}
\hline \multicolumn{1}{|c|}{ Pillar } & \multicolumn{1}{|c|}{ Moto } \\
\hline $\begin{array}{l}\text { Autonomous } \\
\text { maintenance }\end{array}$ & $\begin{array}{l}\text { For an easy maintenance work to be } \\
\text { performed, the organization must be clean. }\end{array}$ \\
\hline $\begin{array}{l}\text { Focused } \\
\text { improvement }\end{array}$ & $\begin{array}{l}\text { Working together proactively, achieve } \\
\text { regular, incremental improvements. }\end{array}$ \\
\hline $\begin{array}{l}\text { Planned } \\
\text { maintenance }\end{array}$ & Minimize unplanned failures \\
\hline $\begin{array}{l}\text { Quality } \\
\text { maintenance }\end{array}$ & $\begin{array}{l}\text { Application of Root Cause Analysis to } \\
\text { eliminate recurring defects. }\end{array}$ \\
\hline $\begin{array}{l}\text { Education and } \\
\text { training }\end{array}$ & $\begin{array}{l}\text { Involving every employee in the } \\
\text { organization and enhancing their } \\
\text { knowledge to fill gaps. }\end{array}$ \\
\hline $\begin{array}{l}\text { Safety, health, } \\
\text { and } \\
\text { environment }\end{array}$ & $\begin{array}{l}\text { Make the working area more comfortable } \\
\text { and sustainable }\end{array}$ \\
\hline Office TPM & $\begin{array}{l}\text { Extend and expand TPM principles to } \\
\text { administrative functions }\end{array}$ \\
\hline $\begin{array}{l}\text { Development } \\
\text { management }\end{array}$ & $\begin{array}{l}\text { Continuously developing ideas and } \\
\text { procedures }\end{array}$ \\
\hline
\end{tabular}

\subsection{Overall Equipment Effectiveness (OEE)}

Assessing the utilization of the existing capacity is a key component to increase production capabilities in manufacturing facilities [8]. Overall Equipment effectiveness $(\mathrm{OEE})$ is a metric and a tool in Total Productive Maintenance (TPM), which is used to maximize equipment effectiveness [9][10]. OEE represents the machine or production line efficiency. In short OEE is described as

$$
O E E=\frac{\text { Valuble qparating Tine }}{\text { zonding Time }}
$$

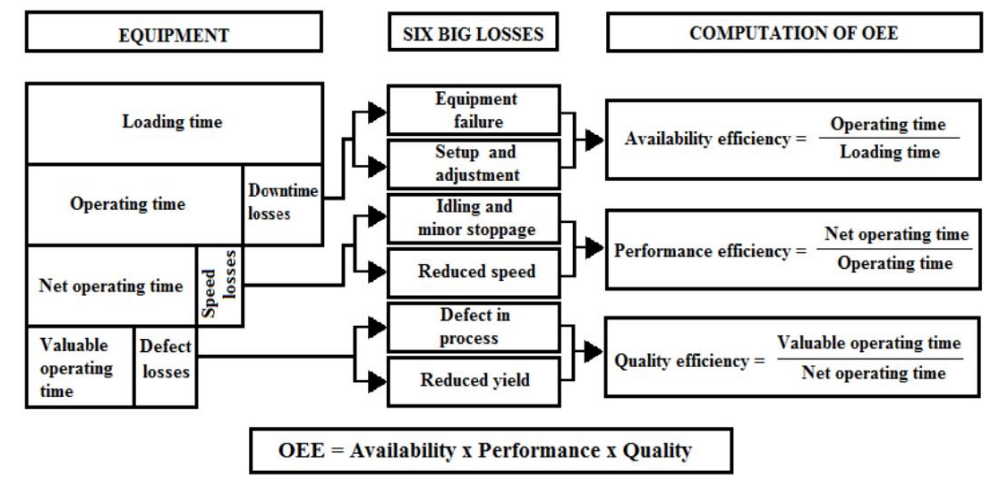

Loading Time $=$ Schedule Time

Figure 2: OEE computation and procedure

Precise values of OEE can be calculated from components such as Availability, Performance and Quality [9][10] which can be calculated:

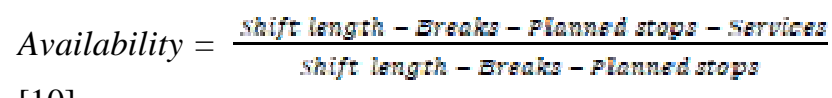
[10]

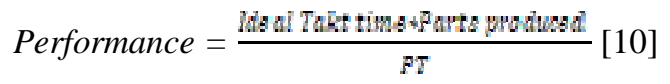

Production Time $(P T)=$ Shift length - Breaks -

Planned stops - Services [10]

Quality $=\frac{\text { Parts Frodused }- \text { Reprosused Farte }}{\text { Parto Froduced }}$ [10]

OEE describes a value but when it is counted machine by machine there will be different kinds of losses encountered and more details about those losses can be studied further to improve the efficiency and effectiveness of the system [9][10]. Taking the OEE as the evaluation index, six big losses such as shutdown loss, transshipment and debugging loss, deceleration loss, starting defective goods loss and manufacturing defective goods loss, are analyzed, and improved in a machine and/or production line[11].

Table 2: Classification of six major losses [11]

\begin{tabular}{|c|c|}
\hline Loss classifications & $\begin{array}{c}\text { OEE loss } \\
\text { classifications }\end{array}$ \\
\hline Downtime loss & Availability Rate \\
\hline Setup and the Debugging loss & Availability Rate \\
\hline Temporary stoppage loss & Performance Rate \\
\hline Deceleration or Speed loss & Performance Rate \\
\hline Defective products loss of starting & Quality Rate \\
\hline $\begin{array}{c}\text { Defective products loss during the } \\
\text { production }\end{array}$ & Quality Rate \\
\hline
\end{tabular}

If these losses are reduced or eliminated there will be a lot of improvement in the OEE. These losses are further discussed in the study conducted. 
D.Phanindra Kshatra et al., International Journal of Emerging Trends in Engineering Research, 8(9), September 2020, 6085 - 6090

\section{Methodology}

OEE is not directed to equipment itself but includes effects of the environment of equipment too [12]. Using the formulas of Availability, Performance and Quality alone will not exactly revel the losses occurred during the functioning of equipment or production line, so after carefully studying and understanding all the parameters [12]. Below is the list of parameters that are considered for the complete and comprehensive calculation of OEE.

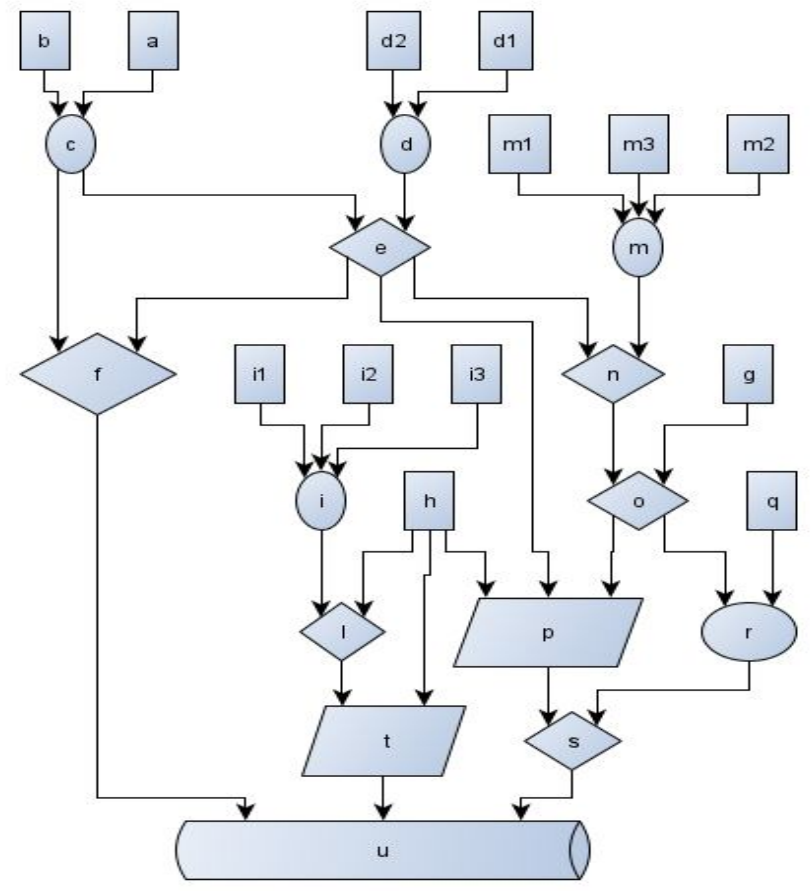

Figure 3: Parameters Flow Chart

Table 3: Parameters Considered for Calculating OEE

\begin{tabular}{|l|l|l|l|}
\hline a & Available Time & $\mathbf{i}$ & Total Defective Output \\
\hline $\mathbf{b}$ & Planned Downtime & $\mathbf{~}$ & Acceptable Output \\
\hline $\mathbf{c}$ & Active Time & $\mathbf{m 1}$ & $\begin{array}{l}\text { Number of Minor } \\
\text { Stoppages }\end{array}$ \\
\hline d1 & Breakdown Time & $\mathbf{m 2}$ & $\begin{array}{l}\text { Average duration of } \\
\text { Minor Stoppages }\end{array}$ \\
\hline d2 & $\begin{array}{l}\text { Setup/Adjustment } \\
\text { Time (Internal Set-up } \\
\text { Time, overall) }\end{array}$ & $\mathbf{m 3}$ & Idling Time \\
\hline d & Major Stoppage Losses & $\mathbf{m}$ & $\begin{array}{l}\text { Minor Stoppages/Idling } \\
\text { Losses }\end{array}$ \\
\hline e & Operating Time & $\mathbf{n}$ & Net Operating Time \\
\hline $\mathbf{f}$ & Operativity Rate & $\mathbf{o}$ & Actual Cycle Time \\
\hline $\mathbf{g}$ & Gross Input & $\mathbf{p}$ & Net Operating Rate \\
\hline $\mathbf{h}$ & $\begin{array}{l}\text { Gross Output (includes } \\
\text { rework) }\end{array}$ & $\mathbf{q}$ & $\begin{array}{l}\text { Ideal (Theoretical, } \\
\text { Design or Optimal) } \\
\text { Cycle Time }\end{array}$ \\
\hline i1 & Start-up Defects & $\mathbf{r}$ & Operating \\
\hline
\end{tabular}

\begin{tabular}{|l|l|l|l|}
\hline & & & Coefficient \\
\hline i2 & Trial Runs Defects & s & Performance Rate \\
\hline i3 & $\begin{array}{l}\text { (Un-reworkable) } \\
\text { Process Defects }\end{array}$ & t & Quality Rate \\
\hline \multicolumn{3}{|c|}{ u = Overall Equipment Effectiveness } \\
\hline
\end{tabular}

\section{Case Study}

This is a case study performed at THATAVARTHI APPARELS LTD a spinning division. The factory produces threads of different sizes to various shirt and/or $t$ shirt industries. This is a big production unit consisting of various departments. Process starts with cotton bales arriving at the storage area and company orders these bales based on customer requirement. Then these cotton bales are laid down according to the requirements and a Bale Plucker machine (individual machine) is used to remove the impurities from these bales. The speed of this Bale Plucker machine is varied depending on the requirement which is a disadvantage for industry. All the extracted cotton which is called as cuffed cotton goes to blow room department through suction process. The cuffed cotton passes through a seed trap where metal parts are removed if any present, and for the further removal of waste from cuffed cotton it passes though different cleaning processes. Once these cleaning processes are done the cuffed cotton enters Carding department where the cuffed cotton is made into cotton webs. This web cotton is drawn into preparatory department to place all the web cotton in boxes and combing process is done where the comber machines make superior and high-quality cotton is extracted for threading purpose. This high-quality cotton thread passes through preparatory department where the machine makes the cotton in spindle format of different sizes and this preparatory department is complex and contains highly automated equipment. Once the spindles are produced, they are transferred to further machines and finally a high-quality yarn thread comes out of the plant and is ready for packing and shipping.

For this case study we had considered Bale Plucker machine only which is an individual machine because the efficiency of the total plant depends on the efficiency of the Bale Plucker machine as it being the one that starts the process.

\subsection{Data Collection and Analysis}

The basic factors where the OEE is dependent on are Availability, Performance, and utilization. Various losses that can occur in the floor parameters from table 3 are considered for OEE calculation. With the help of stop watch for over a period of 2 days, 3 people calculated the time taken by the Bale Plucker to carry out the operation that it is intended to perform had been considered, for the verification of data we have compared the times recorded with the times that are recorded by the industry throughout their operation and the margin of error is only $3 \%$. 


\subsection{Experimental OEE Calculations:}

Using the parameters in Table-3 and the data collected are the Shift Times, Scheduled breaks, Production time, and the downtimes and they are mentioned in the below table 4 and calculations are as follows.

Table 4: OEE Calculation Chart

Equipment ID: Bale Plucker Machine

\begin{tabular}{|c|c|c|c|}
\hline $\mathbf{a}$ & Available Time & $24 \mathrm{hrs}=1400$ & $\min$ \\
\hline b & Planned Downtime & 40 & $\min$ \\
\hline c & Active Time & 1400 & $\min$ \\
\hline d1 & Breakdown Time & 15 & $\min$ \\
\hline d2 & $\begin{array}{l}\text { Setup/Adjustment Time } \\
\text { (Internal Set-up Time, } \\
\text { overall) }\end{array}$ & 15 & $\min$ \\
\hline d & Major Stoppage Losses & 30 & $\min$ \\
\hline e & Operating Time & 1370 & $\min$ \\
\hline $\mathbf{f}$ & Operativity Rate & $97.85 \%$ & $\%$ \\
\hline g & $\begin{array}{l}\text { Gross Input } \\
\text { (includes re-works) }\end{array}$ & $65(10,784$ kgs $)$ & pes \\
\hline h & $\begin{array}{l}\text { Gross Output (includes } \\
\text { rework) }\end{array}$ & $65(10,784$ kgs $)$ & pes \\
\hline i1 & Start-up Defects & $\mathbf{0}$ & pes \\
\hline i2 & Trial Runs Defects & 2 & pes \\
\hline i3 & $\begin{array}{l}\text { (Un-reworkable) } \\
\text { Process Defects }\end{array}$ & $\mathbf{0}$ & pes \\
\hline i & Total Defective Output & 2 & pes \\
\hline 1 & Acceptable Output & 63 & pes \\
\hline m1 & $\begin{array}{l}\text { Number of Minor } \\
\text { Stoppages }\end{array}$ & 1 & - \\
\hline $\mathbf{m} 2$ & $\begin{array}{l}\text { Average duration of } \\
\text { Minor Stoppages }\end{array}$ & 144 & $\min$ \\
\hline m3 & Idling Time & - & $\min$ \\
\hline m & $\begin{array}{l}\text { Minor Stoppages/Idling } \\
\text { Losses }\end{array}$ & 144 & $\min$ \\
\hline $\mathbf{n}$ & Net Operating Time & $1370-144=1226$ & $\min$ \\
\hline $\mathbf{o}$ & Actual Cycle Time & 19.46 & $\min$ \\
\hline $\mathbf{p}$ & Net Operating Rate & $89,48 \%$ & $\%$ \\
\hline $\mathbf{q}$ & $\begin{array}{l}\text { Ideal (Theoretical, } \\
\text { Design or Optimal) } \\
\text { Cycle Time }\end{array}$ & 16 & $\min$ \\
\hline $\mathbf{r}$ & $\begin{array}{l}\text { Operating Speed } \\
\text { Coefficient }\end{array}$ & 0.822 & - \\
\hline $\mathbf{s}$ & Performance Rate & $73.7 \%$ & $\%$ \\
\hline $\mathbf{t}$ & Quality Rate & $96.92 \%$ & $\%$ \\
\hline $\mathbf{u}$ & $\begin{array}{l}\text { Overall Equipment } \\
\text { Effectiveness }\end{array}$ & $69.89 \%$ & $\%$ \\
\hline
\end{tabular}

\section{RESULTS}

Table 4 The OEE of the Bale Plucker Machine calculated is at $69.89 \%$ as indicated in the table 4 above. It can be observed that as defined in the six major losses, even during the active time of 1400 minutes and the machine being run continuously, and the efficiency is not at a greater level.
There is a lot of scope for improvement, which can be done with the help of TPM, TPM will, in turn, can help to improve the OEE systematically.

The Overall Equipment Effectiveness in this industry purely relates to every process from the start to finish. If there is a delay in any single process the whole production will be delayed because of the nature of production system in this industry [13].

First and foremost, the issue here is with cotton being a stock deteriorating item, most of the time the Bale Plucker machine is in constant pressure of running continuously due to various factors like demand and holding cost to store this item, there is a continuous utilization of machine close to $100 \%$ and due to no buffer before this the stock gets piled up[14].

The second problem arises near the Bale Plucker machine area where the dust particles, seeds, iron filings etc. are being separated from the cotton and this is done because to check that the cotton is in its purest form. If any particles are present, it will lead to a lousy quality knit, so this equipment consumes most of the time. If any improvement can be made at this equipment, most of the time can be saved, and more production can be done [15]. Even after impurities separated by the machine if any are found, these are removed by humans mostly by hand. If the machine can be made more accurate or a small second cleaner is attached to this previous one, would decrease human intervention [16].

The third one is that these machines are susceptible if a minor problem occurs, they stop their work. It leads to the stoppage of production with this being a continuous production system, as there are many machines, it is difficult to locate that work is not being done in certain areas if anything can be placed so that it can indicate that work has been stopped in certain areas it would be helpful [17].

One of the significant disadvantages of Bale Plucker machine is that it takes time to remove the seeds and the other dust particles to make the product pure, acceptable, and clean. By this process, it makes more time to refine the material in this process. So, one suggestion to eliminate wastage to improve the quality is that the cleaning process of the material may be done before the operation of the Bale Plucker process [17].

\subsection{Action According to TPM Pillars:}

a) Autonomous maintenance: Preparing the scheduling path of the material and machines are critical to minimize the workload so that it will be easy and flexible to maintain the machines and preparing the checklist also plays an important factor [18].

b) Focused improvement: The most crucial aspect of focused improvement is to have 5S (Sort, Set in Order, Shine, Standardize and Sustain) in the organization. Of all the things standardization is 
most important because once everything is ordered, then one can find a lot of improvements in and around the working of machines, the other thing is to use Kizan tools for improvements in the machine itself [19].

c) Planned maintenance: The most important thing is to record the present status of the machine, prepare a checklist indication the ways the machine is slowing down, make the stock of essential parts which are required for the machine to function, equipment diagnostics techniques and preventive maintenance plan is a must for the machine not to stop during production, and finally evaluate the planned maintenance [19].

d) Quality maintenance: Zero defect condition is the main principle behind quality maintenance. Analyzing the defects that occur in the machine and running in optimum conditions is the essential aspect of quality and the second aspect is to make some standardization by mimicking the parameters to achieve the zero defects in the machine. Since the machine is running continuously throughout the day following the above tow procedures can help the machine to overcome the defects [20].

e) Education and training: One of the foremost vital aspects of working in the textile industry is Education and training on how to use the machines and understand the machines that they are performing. It is essential to know the protocols when the machine needs maintenance and what to do in breakdown situations so that significant production time will not reduce [21].

f) Safety, health, and environment: Working in the textile industry can become dangerous sometimes, but with proper instructions and guidelines it can be preventable, so it is necessary to look after the applying QFD method will help to increase the overall safety, and environmental issues in the textile industry [21].

g) Office TPM: It is to ensure all the support function in an industrial environment are working without any wastage or delay with organizations mission and vision aligned to the goal, No administrative system or process should not affect the productivity for continuous and smooth flow[19].

h) Development management: Once the standardization is achieved in the industry, it is now important to find the wastage, and there is a lot of scope for improvements, though most of the machinery in the textile industry is automated still a lot of work is done manually, so it is essential to have an early development in such areas to capture and rectify all the faults in the system.

\section{CONCLUSIONS AND DISCUSSIONS}

Since the scope of the study is to capture the bottleneck and improve the industry's OEE performance, the authors had only concentrated on a single machine. Still, throughout the industry there can be a lot of improvements to be identified and done [22],[23]. One such improvement that is made with observation is the movement of raw material from storage to area of manufacturing the cotton where potentially there can be improvements through different scheduling processes and usage of automated guided vehicles in different industries through their studies[24],[25]. The authors of this paper will further investigate in these areas of improvement and will continue this work to improve the Overall Equipment Effectiveness for the textile industry.

\section{ACKNOWLEDGEMENT}

The authors would like to acknowledge the management and staff of "THATAVARTHI APPARELS LTD" for their support during the conduction of the case study and successful competition of this project, and the authors would like to thank Head of the Department, Mechanical Engineering, K L Deemed to be University, for encouraging the team to work on field and help this work get a result oriented approach.

\section{REFERENCES}

[1] Sujith Gulhani, Ranjit Turukmane, Effect of Make in India on Textile Sector, Journal of Textile Engineering \& Fashion Technology, Volume 3 Issue 1 - 2017, DOI: 10.15406/jteft.2017.03.00084

[2] Ahuja, I.P.S. and Khamba, J.S. 2008. Total productive maintenance: Literature review and directions. International journal of quality \& reliability management. London, UK : Emerald group publishing limited, 2008. Vol. 25, 7. ISSN: 0265-671X.

[3] T.Venkata Deepthi, K.Ramakotaiah, K.Krishnaveni, Research on Performance of Multi-Skilled Workers for Sustainable Production Planning In Seru Production Systems, International Journal of Innovative Technology and Exploring Engineering (IJITEE)

ISSN: 2278-3075, Volume-8 Issue-10, August 2019

[4] A. K. Gupta and R. K. Garg, "OEE improvement by TPM implementation: a case study", International Journal of IT, Engineering and Applied Sciences Research, vol. 1, no. 1, pp. 115-124, 2012.

[5] T. Suzuki, TPM in process industries. CRC Press, 1994. [6] Trinath Sahoo, 7. Improving Overall Equipment Effectiveness (OEE) of Process Plant Equipments Through E-Diagnostics, Indian Oil Corporation Ltd 
[7] S. Nakajima, "Introduction to TPM: Total Productive Maintenance.", Productivity Press, Inc., 1988

[8] Stuart Giegling, Dr. William A. Verdini, Tim Haymon and Dr. John Konopka, Implementation of Overall Equipment Effectiveness (OEE) System at a Semiconductor Manufacturer, 0-7803-3929-0/97 \$8.00 01997 IEEE, ElectronicsManufacturingTechnology Symposium

[9] Ir.K.Batumalay, Dr.A.S.Santhapparaj, Overall Equipment Effectiveness (OEE) through Total Productive Maintenance (TPM) Practices - A Study across the Malaysian Industries

[10] T. Rautio, K. Kutuniva, J. Makikangas, K. Mantyjarvi, Simple and Cost Effective System for Overall Equipment Efficiency Measurement, 978-1-5386-6786-6/18/\$31.00 (C)2018 IEEE

[11] Xiaoping ZHU, Analysis and Improvement of Enterprise's Equipment Effectiveness Based on OEE.

[12] A. J. de Ron and J. E. Rooda, Equipment Effectiveness: OEE Revisited, IEEE Transactions on Semiconductor Manufacturing, VOL. 18, NO. 1, February 2005

[13] Rakhi Ashok Deshpande, P. V. Rama Rao, Developing Mathematical Models \& Methodologies to Overcome Lean Strategy Selection \& Leanness Assessment Problems, International Journal of Recent Technology and Engineering (IJRTE), ISSN: 2277-3878, Volume-8 Issue-2, July 2019

[14] Pavan Kumar, An inventory planning problem for time-varying linear demand and parabolic holding cost with salvage value, Croatian Operational Research Review, CRORR 10(2019), 187-199

[15] K. V. Durga Rajesh, P. V. Chalapathi, Performance Analysis of Enhanced Cell Formation Techniques in a Manufacturing Industry - A Case Study, International Journal of Innovative Technology and Exploring Engineering (IJITEE), ISSN: 2278-3075, Volume-8 Issue-6, April 2019

[16] G. Yedukondalu, Mayur. Thakare, V. Anvesh, R. Hokesh Reddy, Akin Cheetri, Scheduling and Control of Parts in FMS industry, International Journal of Engineering \& Technology, 7 (2.24) (2018) 214-219

[17] T. Venkata Deepthi, K. Ramakotaiah, Vijaya Kumar Manupati, Chaitanya Gangal, Investigating the performance improvement by conversion of assembly line configuration to a pure cell system in manufacturing industry, European J. Industrial Engineering, Vol. 13, No. 6, 2019

[18] M. B. S. Sreekara Reddy, D. Naga Varshith, G. Praveen, V. Vasanth Kumar \& K. Prem Chand, Evolutionary Algorithmic Approach to Solve a Flexible Job Shop Sscheduling Problem using Modified Particle Swarm Optimization, International Journal of Mechanical and Production Engineering Research and Development (IJMPERD), ISSN (P): 2249-6890; ISSN (E): 2249-8001, Special Issue, Jun 2018, 261-268

[19] F. Lee Cooke, "Implementing TPM in plant maintenance: some organizational barriers", International
Journal of Quality \& Reliability Management, vol. 17, no. 9, pp. 1003-1016, 2000.

[20] Sachit Vardhan, Pardeep Gupta, Vaibhav Gangwar, The Impact of Quality Maintenance Pillar of TPM on Manufacturing Performance, Proceedings of the 2015 International Conference on Industrial Engineering and Operations Management Dubai, United Arab Emirates (UAE), March 3 - 5, 2015.

[21] Rajaprasad, S.V.S \& Chalapathi, PV, Quality Function Deployment Method for Ascertaining Influential Factors on Transfer of Safety Trainig Skills in Indian Construction Organizations, Journal of Technical Education and Training (JTET), Vol. 8, No.1, June 2016, ISSN 2229-8932

[22] K. Prakash Babu, V. Vijaya Babu and Nageswara Rao Medikondu, Implementation of heuristic algorithms to synchronized planning of machines and AGVs in FMS, Management Science Letters 8 (2018) 543-554

[23] K. Prakash Babu, V. Vijaya Babu and Nageswara Rao Medikondu, Fuzzy heuristic algorithm for simultaneous scheduling problems in flexible manufacturing system, Management Science Letters 8 (2018) 1319-1330

[24] Medikondu Nageswararao, Makkena Naveenkumar, Majety Vamshimohan, Gandham Jitendra Krishna, Scheduling of Machines and Automated Guided Vehicles in FMS using Shuffled Frog Leap Algorithm, International Journal of Mechanical Engineering and Technology (IJMET) Volume 8, Issue 5, May 2017, pp. 496-503

[25] P Anil Kumar, M Nageswara Rao, T Yeswanth Kumar, M Manish Kumar, V Bhanu, Scheduling of Machines and Automated Guided Vehicles in FMS using Scatter Search Algorithm, International Journal of Mechanical Engineering and Technology (IJMET), Volume 8, Issue 5, May 2017, pp. $471-481$ 